\title{
Impact of Irrigation and Nutrients on the Performance of Bajra Napier Hybrid Grass Grown under Light Sandy Soil
}

\author{
C. Vennila* and T. Ananthi \\ Department of Agronomy, Madras Veterinary College, Chennai 7, Tamil Nadu, India \\ *Corresponding author
}

\section{Ke ywords}

Irrigation methods,

Nutrient sources,

Leaf stem ratio,

Nutrient uptake,

Fodder quality

Article Info

Accepted:

07 May 2019

Available Online:

10 June 2019
A B S T R A C T

The study was carried out at university Research Farm, Tamil Nadu Veterinary and Animal Sciences University, under light textured soils. The treatments consisted of three irrigation levels viz., $\mathrm{I}_{1}$ : drip irrigation at $100 \%$ Potential Evapo transpiration (PE), $\mathrm{I}_{2}$ : drip irrigation at $75 \% \mathrm{PE}$ and $\mathrm{I}_{3}$ : surface irrigation, and three nutrient levels viz., $\mathrm{F}_{1}$ : Farm Yard Manure (FYM) $25 \mathrm{t} \mathrm{ha}^{-1}+50 \%$ recommended dose of fertilizers (RDF), $\mathrm{F}_{2}:$ FYM $25 \mathrm{t} \mathrm{ha}^{-1}$ $+100 \%$ RDF and $\mathrm{F}_{3}: 100 \%$ RDF. Cumulative irrigation water was calculated and applied as per the treatment schedule. Plant samples were analyzed for macro nutrients and uptake of nutrients by plants was calculated. Chlorophyll content was estimated periodically. Plant vegetative growth and yield contributing characteristics were measured to relate with irrigation frequency and nutrients. The nutrient uptake by plants had more influence on growth and yield of plants. Irrigation through drip at $100 \%$ PE maintained the moisture availability throughout the crop growth period. Highest leaf chlorophyll content (SPAD Values) (38.8 and 25.7) was obtained with application of FYM $25 \mathrm{t} \mathrm{ha}^{-1}+100 \%$ RDF and drip irrigation at $100 \%$ PE. The yield was found higher with the application of FYM $25 \mathrm{t}$ $\mathrm{ha}^{-1}+100 \% \mathrm{RDF}$ and drip irrigation at $100 \%$ PE. Crude protein content of bajra napier hybrid grass was significantly influenced with nutrient and irrigation levels.

\section{Introduction}

Fodder is cheap source of nutrient supply than concentrate feed and needs to be given more emphasis so as to make the dairy industry economically viable. In India limited land $(8.6 \mathrm{~m} \mathrm{ha})$ is available for fodder cultivation (Kumar et al., 2012) and our country face the shortage of both green as well as dry fodder by about 61.1 and 21.95, respectively (Sathyanarayan et al., 2017). Bajra napier hybrid grass is an important perennial fodder crop of India and widely cultivated. Among the varieties of bajra napier hybrid grass, variety $\mathrm{Co} \mathrm{CN} 4$ is the predominantly cultivated due to its high yielding potential and perennial in nature (Anthony and Thomas, 2014).

Bajra napier hybrid grass is a perennial crop and can be maintained in the field for about 4 to 6 years (Rahman and Talukder, 2015). Hence, it requires continuous irrigation for better productivity. However, farmers have 
tendency to apply huge quantity of water with large irrigation interval creating water logging condition (Marathe et al., 2001) especially in surface irrigation method. Bajra napier hybrid grass have large feeder roots on the top layer. Whenever, irrigation water is led in on surface layers that lead to imbalance in nutrient uptake thereby adversely affecting growth of the plants (Marathe et al., 2016).

The irrigation frequency defined by interval between two successive irrigations should be used in a way so as not to compromise the water needs of the plant in their critical phonological stages (Sousa et al., 2014). Earlier studies have shown significant results under different irrigation frequencies on high value crops (Lal and Kumar, 1997, Jain and Tiwari, 2012) under different soil and climatic conditions. Application of water in small doses at frequent intervals ensures their optimum utilization and higher crop yields. This also reduces percolation and evaporation losses, and improves water use efficiency by maintaining optimum soil moisture in the vicinity of the root zone.

Apart from water, nutrients are also essential for the better growth and productivity of crops. The removal of nutrients by the high yielding crops especially perennial crops causes nutrient imbalances over the time, with degradation of soil reserves of nutrients (Martha Júnior et al., 2004). Hence, to increase the yield and to replenish the soil, nutrient uptake of a particular crop should be known and replenished accordingly. Various nutrient sources are available and applied to boost the growth and yield of crops (Lemaire, 1989)

In bajra napier hybrid grass, information on irrigation requirement, method of irrigation, frequency and nutrient application is meager. In this perspective, the present investigation was undertaken to evaluate the influence of different frequencies on yield, quality and nutrient uptake of bajra napier hybrid grass grown on light textured soils of North Eastern zone of Tamil Nadu.

\section{Materials and Methods}

The field experiment was conducted at University Research Farm, Tamil Nadu Veterinary and Animal Sciences University, Chennai. Tamil Nadu. The climate of the study area is tropical with hot summer and moderate winter with average annual rainfall of 800-1400 mm occurring mostly during North East monsoons (October to December). Average monthly minimum and maximum temperature during the experimental period varied from 19 and $41.9^{\circ} \mathrm{C}$ during 2014-2015 and 16.7 and $41.6^{\circ} \mathrm{C}$ during 2015-2016, respectively. Cumulative pan evaporation for six days ranged between $6.6 \mathrm{~mm}$ to $13.8 \mathrm{~mm}$. The weather condition during both the years of study was close to normal. The field capacity and permanent wilting point of soil was $26.2 \%$ and $12.3 \%$ respectively. The soil of the experimental field was sandy in texture and had low levels of organic carbon $(0.37 \%)$ and medium levels of available nitrogen $\left(242.8 \mathrm{~kg} \mathrm{ha}^{-1}\right)$, available phosphorus $(18.6 \mathrm{~kg}$ $\mathrm{ha}^{-1}$ ) and available potassium (248.6 $\left.\mathrm{kg} \mathrm{ha}^{-1}\right)$, with a $\mathrm{pH}$ of 7.64 .

The experiment was arranged in factorial randomized block design with three irrigation levels and three nutrient levels in four replications in a plot size of $4 \mathrm{~m} \times 3.5 \mathrm{~m}$. The irrigation levels included $\mathrm{I}_{1}$ : drip irrigation at $100 \% \mathrm{PE}, \mathrm{I}_{2}$ : drip irrigation at $75 \% \mathrm{PE}$ and $\mathrm{I}_{3}$ : surface irrigation while, nutrients: $\mathrm{F}_{1}$ : Farm Yard Manure (FYM) $25 \mathrm{t} \mathrm{ha}^{-1}+50 \%$ Recommended dose of fertilizers (RDF), $\mathrm{F}_{2}$ : FYM $25 t^{-1}+100 \%$ RDF and $F_{3}: 100 \%$ RDF. The quantity of recommended nutrients for bajra napier hybrid grass is 150:50:50 kg NPK ha ${ }^{-1}$. The calculated quantity of fertilizers viz., urea, single super phosphate 
and muriate of potash were applied as per the treatment schedule. For drip irrigation treatments, the amount of water applied corresponded to the sum of ETc in the corresponding period. The crop water requirement of bajra napier hybrid grass was computed using

\section{$\mathrm{V}=\mathrm{Ep} \times \mathrm{Kp} \times \mathrm{Kc} \times \mathrm{Sc} \times \mathrm{Wp}$}

Where, V - Volume of water (litre day ${ }^{-1}$ plant $^{-1}$ ), Ep - Open Pan Evaporation (mm day $^{-1}$ ), Kp - Pan Coefficient, Kc - Crop coefficient, Sc - Crop spacing (row to row $\mathrm{x}$ plant to plant in $\mathrm{m}$ ) and $\mathrm{Wp}$ - Wetting factor (Mane et al., 2006). Irrigation efficiency of drip was considered as $90 \%$. The effective rainfall was calculated by balance sheet method from the actual rainfall received and was used for daily water requirement of crop. Irrigation was provided using drip method of irrigation, having one dripper for two rows of plants. Measured quantity of irrigation water was provided to the plants using water meters and separate valve adjustments for every treatment. Quantity of irrigation water was applied based on the calculated quantity. On an average, the irrigation water was applied once in 6 days.

The crop was planted during the first week of January 2014 and the trial was under study for two years with repeated harvest. The intercultural operations, like weed management were done well in time in all plots judiciously after every harvest during both the years of study. The first harvest of Bajra Napier hybrid grass was done at 75 days after planting and subsequently once in 45 days. About six harvests were done during first and second years of the study. Cumulative yield was calculated per year per hectare. Leaf stem ratio was worked out based on leaf weight $\left(\mathrm{g}_{\text {plant }}{ }^{-1}\right)$ and stem weight $(\mathrm{g}$ plant $^{-1}$ ). From the yield of total dry matter and contents of nitrogen, phosphorus and potassium the total uptake of respective nutrients was worked out using the procedure suggested by Piper (1966) and expressed in $\mathrm{kg}$ $\mathrm{ha}^{-1}$.

Nutrient uptake $\left(\mathrm{kg} \mathrm{ha}^{-1}\right)=$

Nutrient content $(\%) \times$ Total DMP in $\mathrm{kg} \mathrm{ha}^{-1}$ 100

Crude protein content was computed by multiplying the $\mathrm{N}$ content (estimated from the di-acid digest by micro-kjeldhal method) with the factor 6.25 and expressed in per cent. Crude fibre was estimated gravimetrically by successive digestion and washing a weighed plant sample with dilute acid and alkali. The material left un-dissolved was considered as crude fibre and expressed in percentage. Ether extract (an estimate of crude fats and oils) was estimated gravimetrically by subjecting a weighed, powdered plant sample to continuous extraction with petroleum ether at 40 to $50^{\circ} \mathrm{C}$ in a Soxhlet extraction apparatus and expressed in percentage.

Statistical analysis: All the recorded data from the experiment were statistically analyzed using the F-test as per the standard statistical procedure (Gomez and Gomez, 1984) and values of critical difference $(\mathrm{CD})(\mathrm{P}=0.05)$ were used to determine the significance of difference between the treatment means.

\section{Results and Discussion}

\section{Fodder biomass}

Pertaining to irrigation levels, drip irrigation at $100 \%$ PE resulted in higher biomass yield of $259.17 \mathrm{t} \mathrm{ha}^{-1}$ and $296.78 \mathrm{t} \mathrm{ha}^{-1}$ and leaf stem ratio of 0.72 and 0.76 during 2014 and 2015 respectively. Application of FYM $25 \mathrm{t}$ $\mathrm{ha}^{-1}+100 \% \mathrm{RDF}$ resulted in higher biomass of $332.35 \mathrm{t} \mathrm{ha}^{-1}$ and $354.2 \mathrm{t} \mathrm{ha}^{-1}$ during the first and second years of experimentation respectively but comparable with the application of FYM $25 \mathrm{t} \mathrm{ha}^{-1}+50 \% \mathrm{RDF}$ 
during both the years of experimentation. Higher yield of fodder obtained due to addition of irrigation at optimum soil moisture and nutrients may be attributed to the fact that $\mathrm{N}$ is an important constituent of amino acids and chloroplasts which directly influenced plants leaf area, growth and development through greater photosynthates. Higher leaf area captures more photosynthetically active radiation with higher photosynthesis as there is more number of leaves which ultimately reflected on the yield of the crops. Similar findings were also reported by Kumar and Sharma, (1997) and Singh and Nepalia (2009).

Combined application of FYM and inorganic fertilisers had synergistic effect on increasing the source to sink ratio, thereby the yield (Vennila et al., 2017). Application of Farm yard manure @25 t ha ${ }^{-1}$ along with 100\% RDF resulted in higher nutrient uptake by plants followed by application of $25 \mathrm{t} \mathrm{ha}^{-1}$ of FYM along with 50\% RDF. Nutrient application through drip irrigation had beneficial effect on enhanced crop growth such as plant height, number of tillers and number of leaves which in turn has resulted in higher biomass yield per plant and per hectare. This might be due to the fact that nutrients are evenly distributed in the root zone area of the crop when applied through fertigation plots and thereby reducing the loss of nutrients by volatilization and leaching. Hence, continuous availability of soil moisture could result in continuous availability of moisture, in turn resulting in higher plant nutrient uptake. This is in line with the findings of Vennila and Sankaran (2017). Further, as there is optimum availability of water and nutrients for the plants, there is limited wastage of nutrients in the soil, hence resulting in higher uptake of nutrients by the plants (Sureshkumar et al., 2016). The interaction effects between irrigation and nutrients were significant indicating that soil moisture is essential for nutrient uptake by the plants (Singh, 2002).

\section{Nutrient uptake}

Amongst macronutrients, maximum nitrogen and potassium uptake of bajra napier hybrid grass was observed with the application of irrigation through drip at $100 \% \mathrm{PE}$ followed by irrigation through drip at $75 \% \mathrm{PE}$. Water application at $100 \% \mathrm{PE}$ and $75 \% \mathrm{PE}$ were found most effective due to irrigation water application at proper interval i.e. dependent on the potential evapo transpiration. Most of the nutrient absorption processes are aerobic in nature and periodical application of irrigation might have maintained good aeration in soil which resulted in higher uptake of these nutrients by the plants.

The greater $\mathrm{N}, \mathrm{P}$ and $\mathrm{K}$ uptake with continuous availability of water was reported earlier by $\operatorname{Rad}$ (2011). Treatments with surface irrigation recorded significantly low nutrient uptake in plants. In this treatment, application of higher amount of water initially might have favoured leaching of nutrients from the soil. Similarly, occurrence of low soil moisture content between two subsequent high interval irrigations treatments favoured poor nutrient absorption by the plants. The findings corroborates with the findings of Haneef et al., (2014) and Sharma et al., (2015) who reported decreased uptake of N, P and $\mathrm{K}$ with lower soil moisture levels.

Chlorophyll content in the leaves of the plants, as expressed by SPAD values, significantly varied amongst the treatments (Table 1). It was the highest in irrigation through drip at $100 \%$ PE and application of $100 \%$ RDF along with FYM $25 \mathrm{t} \mathrm{ha}^{-1}$. Thus indicating better photosynthetic capacity of the plants, this might be due to better nutrient uptake and availability of ample water to the plants (Table 2). 
Table.1 Yield and nutrient uptake of bajra napier hybrid grass as influenced by irrigation and nutrients

\begin{tabular}{|c|c|c|c|c|c|c|c|c|c|c|c|}
\hline \multirow[t]{2}{*}{ Treatments } & \multicolumn{2}{|c|}{ Biomass } & \multicolumn{2}{|c|}{ Leaf stem ratio } & \multicolumn{2}{|c|}{ N uptake (kg/ha) } & \multicolumn{2}{|c|}{ P uptake (kg/ha) } & \multicolumn{2}{|c|}{ K uptake (kg/ha) } & \multirow{2}{*}{$\begin{array}{c}\text { Chlorophyll } \\
\text { content } \\
\text { (SPAD value) } \\
\text { (Mean) }\end{array}$} \\
\hline & 2014-15 & 2015-16 & 2014-15 & 2015-16 & 2014-15 & 2015-16 & 2014-15 & 2015-16 & 2014-15 & 2015-16 & \\
\hline \multicolumn{12}{|l|}{ Irrigation } \\
\hline $\mathbf{I}_{1}$ & 206.51 & 262.93 & 0.63 & 0.48 & 103.3 & 129.6 & 34.0 & 42.6 & 93.0 & 116.6 & 19.7 \\
\hline $\mathbf{I}_{2}$ & 259.17 & 296.78 & 0.72 & 0.76 & 136.1 & 153.9 & 51.0 & 56.5 & 123.7 & 139.6 & 25.7 \\
\hline $\mathbf{I}_{3}$ & 185.23 & 235.95 & 0.51 & 0.33 & 86.0 & 111.8 & 27.9 & 36.5 & 77.5 & 100.1 & 15.4 \\
\hline \multicolumn{12}{|l|}{ Nutrients } \\
\hline $\mathbf{F}_{1}$ & 261.83 & 317.30 & 0.58 & 0.53 & 145.7 & 156.2 & 48.5 & 51.9 & 131.8 & 141.2 & 21.6 \\
\hline $\mathbf{F}_{2}$ & 332.35 & 354.20 & 0.63 & 0.59 & 179.9 & 192.7 & 78.3 & 81.3 & 164.5 & 175.9 & 38.8 \\
\hline $\mathbf{F}_{3}$ & 195.43 & 247.42 & 0.49 & 0.48 & 93.5 & 119.2 & 30.8 & 39.3 & 83.8 & 88.3 & 19.1 \\
\hline \multicolumn{12}{|l|}{$\operatorname{CD}(5 \%)$} \\
\hline I & 8.62 & 6.9 & - & - & 11.98 & 9.86 & 5.39 & 4.65 & 11.04 & 8.99 & 1.18 \\
\hline $\mathbf{F}$ & 7.69 & 7.01 & - & - & 9.92 & 8.44 & 4.49 & 3.93 & 9.13 & 7.94 & 1.93 \\
\hline I at F & 12.89 & 13.21 & - & - & 20.13 & 16.78 & 9.09 & 7.92 & 18.53 & 15.65 & 2.16 \\
\hline
\end{tabular}

$\mathrm{I}_{1}$ : Drip irrigation at $100 \%$ PE, $\mathrm{I}_{2}$ : Drip irrigation at $75 \%$ PE and $\mathrm{I}_{3}$ : Surface irrigation, $\mathrm{F}_{1}$ : Farm Yard Manure $25 \mathrm{t}^{-1}+50 \% \mathrm{RDF}^{-1} \mathrm{~F}_{2}$ : FYM $25 \mathrm{t} \mathrm{ha}{ }^{-1}+100 \%$ $\mathrm{RDF}$ and $\mathrm{F}_{3}: 100 \% \mathrm{RDF}$ alone. 
Table.2 Proximates of Bajra Napier hybrid grass as influenced by irrigation and nutrients

\begin{tabular}{|c|c|c|c|c|c|c|c|c|c|c|}
\hline \multirow[t]{2}{*}{ Treatments } & \multicolumn{2}{|c|}{$\begin{array}{c}\text { Crude protein content } \\
(\%)\end{array}$} & \multicolumn{2}{|c|}{$\begin{array}{c}\text { Crude fibre content } \\
(\%)\end{array}$} & \multicolumn{2}{|c|}{$\begin{array}{c}\text { Ether content } \\
(\%)\end{array}$} & \multicolumn{2}{|c|}{ Ash content $(\%)$} & \multicolumn{2}{|c|}{$\begin{array}{l}\text { Acid insoluble ash content } \\
\qquad(\%)\end{array}$} \\
\hline & 2014-15 & 2015-16 & 2014-15 & 2015-16 & 2014-15 & 2015-16 & 2014-15 & 2015-16 & 2014-15 & 2015-16 \\
\hline \multicolumn{11}{|l|}{ Irrigation } \\
\hline $\mathbf{I}_{1}$ & 6.89 & 7.41 & 24.62 & 21.5 & 1.7 & 1.57 & 12.72 & 10.91 & 5.38 & 6.94 \\
\hline $\mathbf{I}_{2}$ & 7.84 & 7.63 & 25.01 & 21.6 & 1.87 & 1.62 & 10.86 & 9.40 & 4.13 & 3.68 \\
\hline $\mathbf{I}_{3}$ & 7.41 & 7.24 & 25.64 & 22.09 & 1.88 & 1.78 & 13.28 & 8.04 & 5.00 & 5.6 \\
\hline \multicolumn{11}{|l|}{ CD (5\%) } \\
\hline \multicolumn{11}{|l|}{ Nutrients } \\
\hline $\mathbf{F}_{1}$ & 7.64 & 7.38 & 26.54 & 21.24 & 1.75 & 1.72 & 12.73 & 8.67 & 4.98 & 5.52 \\
\hline $\mathbf{F}_{2}$ & 7.83 & 7.94 & 24.29 & 23.64 & 1.60 & 1.51 & 12.70 & 9.20 & 5.42 & 5.06 \\
\hline $\mathbf{F}_{3}$ & 6.53 & 7.30 & 25.21 & 21.18 & 1.90 & 1.76 & 13.81 & 9.55 & 4.48 & 4.54 \\
\hline \multicolumn{11}{|l|}{ CD $(5 \%)$} \\
\hline I & 0.53 & 0.32 & NS & NS & 0.14 & 0.05 & NS & NS & NS & NS \\
\hline $\mathbf{F}$ & 0.46 & 0.75 & NS & NS & 0.16 & 0.07 & NS & NS & 0.19 & 0.25 \\
\hline
\end{tabular}

$\mathrm{I}_{1}$ : Drip irrigation at $100 \%$ PE, $\mathrm{I}_{2}$ : Drip irrigation at $75 \%$ PE and $\mathrm{I}_{3}:$ Surface irrigation, $\mathrm{F}_{1}:$ Farm Yard Manure $25 \mathrm{t} \mathrm{ha}^{-1}+50 \%$ RDF, $\mathrm{F}_{2}: \mathrm{FYM}_{25} \mathrm{t}$ ha ${ }^{-1}+100 \%$ $\mathrm{RDF}$ and $\mathrm{F}_{3}: 100 \% \mathrm{RDF}$ alone 
Increased uptake of $\mathrm{Fe}$ due to enhanced uptake of nutrients might also play an important role in chlorophyll formation (Marathe et al., 2017). Increased contents of chlorophyll in leaves due to alternated drip irrigation was reported earlier (Liu, 2016) in coffee trees. Drastic reduction in leaf chlorophyll content was recorded in surface irrigated plots and with the application of inorganic nutrients alone.

\section{Fodder quality}

Different irrigation and nutrients had significant influence on quality parameters like crude protein, ether extract and Acid insoluble ash (AIA), whereas, treatments did not show significant influence on crude fibre content and total ash content of Bajra Napier hybrid grass. Among different treatments, irrigation at $75 \%$ PE registered significantly maximum crude protein content $(7.84 \%)$ but was at par with surface irrigation. Whereas, during second year, irrigation at $75 \% \mathrm{PE}$ registered higher crude protein content of 7.63 $\%$ and was comparable with crude protein content registered from irrigation through drip at $100 \%$ PE. Nutrient application to Bajra Napier hybrid grass resulted in significant production of crude protein content. Application of FYM $25 \mathrm{t} \mathrm{ha}^{-1}+100 \% \mathrm{RDF}$ through drip at $100 \% \mathrm{PE}$ recorded the higher crude protein content but at par with treatment which received inorganic nutrients alone. There was no significant difference in crude fibre and total ash content due to irrigation and nutrient application. However, surface irrigation to plants resulted in higher crude fibre and total ash content of the plants. With respect to nutrients, lower the application of nutrients, higher the crude fibre and total ash content. The AIA content of bajra napier hybrid grass was not influenced by irrigation treatments. However, application of nutrients had significant influence on the AIA content. The results showed that application of FYM
$25 \mathrm{t} \mathrm{ha}^{-1}+100 \%$ RDF through drip resulted in higher AIA \% followed by application of FYM $25 \mathrm{t} \mathrm{ha}^{-1}+50 \%$ RDF through drip, during both the years of experimentation. The present findings are in conformity with the findings of Vijayakumar et al., (2009) and Senthil et.al. (2016). It has been concluded that better performance of bajra napier hybrid grass could be achieved by application of tested irrigation methods and nutrient in light sandy soils.

\section{References}

Anthony, S and C.G. Thomas. 1990. Nutritive quality of hybrid Napier cultivars grow under rainfed ecosystem. J. of Trop. Agric., 52(1): 90-93 (2014). AOAC: Official Methods of Analysis. Association of Official Analytical Chemists, Arlington, Virginia 22201 USA, pp. 17-19.

Gomez, K.A. and A.A. Gomez. 1984. Statistical Procedures for Agricultural Research. $2^{\text {nd }}$ Edition, John Wiley.

Haneef, M., R.A. Kaushik, D.K. Sarolia, A. Mordia and M. Dhakar. 2014. Irrigation scheduling and fertigation in pomegranate cv. Bhagawa under high density planting system. Indian J. Hort., 71, 45-48.

Jain, P.K. and A. Tiwari. 2012. Effect of irrigation systems and frequencies on growth and yield of papaya. Indian $J$. Hort., 69, 277-280.

Kumar, S., R. Agrawal, A. K. Dixit, A. K., Rai, J.B. Singh and S.K. Rai. 2012. Forage production technology for arable lands. Indian Grassland and Fodder Research Institute, Jhansi-284003, 1.

Kumar. S. and B.L. Sharma.1997. Effect of FYM, nitrogen and Azospirillum inoculation on yield and quality of fodder sorghum. Forage Res., 28, 165168.

Lal, R.L. and G. Kumar. 1997. Effect of 
irrigation frequencies on yield and quality of litchi fruits cv. Rose scented. Indian J. Hort., 54, 10-15.

Liu, X., F.Li, Q. Yang and X. Wang. 2016. Effect of alternate drip irrigation and superabsorbent polymer on growth and water use of young coffee tree. $J$. Environ. Biol. 37, 485-491.

Mane, M.S., B.L. Ayare and S.S. Magar. 2006. Principles of drip irrigation system, Jain Brothers, New Delhi, pp. 24-87.

Marathe, R.A., A.A. Murkute and K.D.Babu.2016. Mineral nutrient deficiencies and nutrient interactions in pomegranate. Natl. Acad.Sci.Lett., 39, 407-410.

Marathe, R.A., J. Sharma, A.A. Murkute and K.D. Babu. 2017. Response of nutrient supplementation through organics on growth, yield and quality of pomegranate. Sci. Hortic., 214, 114121.

Marathe, R.A., S. Mohanty and S. Singh. 2001. Waterlogging - as a soil related constraint to performance of Nagpur mandarin orchards. Agropedology. 11, 134-138.

Piper, C.S: Soil and plant analysis. 1966. Hans Publishers, Bombay.

Rad, P.M.R., S.A.R. Movahedi Naeini and M. Pessarakli. 2011. Nutrient uptake, soil and plant nutrient content and yield components of wheat plants under different planting systems and various irrigation frequencies. J. Plant Nutr., 34, 1133-1143.

Rahman, M. Z., and M.A.I. Talukder. 2015. Production and nutritional quality of high yielding fodders in the coastal areas for ruminants. The Agriculturist, 13(1): $1-8$.

Satyanarayan, K., J. Shilpa Shree, V. Jagadeeswary and Lalith Achoth. 2017. District-Wise Demand and Supply of Fodder (Crop Residues) Production in
Karnataka - A Gap Analysis. Int. J. of Livestock Res., 7 (7), 123-131.

Senthil, M., C.S. Balusami, K. K. Jiji and M.M. Asif. 2016. Proximate composition, fibre fraction values of environmentally adapted fodder varieties in Wayanad district, Kerala, India. Int. J. of Science, Environment and Technology, 5 (5): 2855-2860.

Sharma, R., S.K. Pandey and T.A. Sharma. 2015. Influence of soil moisture on growth and nutrient content in healthy and malformed panicles of mango varieties. Indian J. Hort., 72, 133-138.

Singh D and V. Nepalia. 2009. Influence of integrated nutrient management on quality protein maize productivity and soils of southern Rajasthan. Indian. J. Agric. Sci., 79: 1020-1022.

Singh, H.P: Precision Farming in Horticulture. 2002. In: Proceedings of the National Seminar cum Workshop on Hi- Tech Horticulture and Precision Farming. 26- 28 July 2012, Lucknow. pp. 1-20.

Singh, S.D. and S.N. Dubey. 2007. Soil properties and yield of fodder oat as influenced by source of plant nutrient and cutting management. Forage. Res., 33,101- 103.

Sousa, V.F., B.M. Azevedo, C.N.V. Fernandes, T.V.A. Viana and M.S.L.Silva. 2014. Growth, gas exchange and yield of peanut in frequency of irrigation. Revista Ciencia Agronomica, 45, 27-34.

Sureshkumar, P., P. Geetha, M.C.Narayanan Kutty, C. Narayanan Kutty and T. Pradeepkumar. 2016. Fertigation - the key component of precision farming. Journal of Trop. Agri., 54 (2), 103-114.

Vennila, C and V.M. Sankaran. 2017. Influence of Nutrients on Growth and Yield of Bajra Napier Hybrid Grass. Current J. of Applied Science and Technology, 23(5): 1-6. 
Vennila, C, V.M. Sankaran and C. Nithya. 2017. Influence of nutrients on yield and nutrient uptake of bajra napier hybrid grass. Int. J. of Chemical Studies, 5(6): 1444-1448.
Vijayakumar, G., C. Babu, K. Velayudham, and T.S. Raveendran. 2009. A high yielding Cumbu Napier hybrid grass CO (CN) 4. Madras Agric. J., 96 (7-12), 291-292.

\section{How to cite this article:}

Vennila, C. and Ananthi, T. 2019. Impact of Irrigation and Nutrients on the Performance of Bajra Napier Hybrid Grass Grown under Light Sandy Soil. Int.J.Curr.Microbiol.App.Sci. 8(06): 804-812. doi: https://doi.org/10.20546/ijcmas.2019.806.097 